\title{
Effects of Different Levels of Protein Intake and Physical Training on Growth and Nutritional Status of Young Rats
}

\author{
Sandra Maria Lima RIBEIRO ${ }^{1}$, Marcelo Macedo Rogero ${ }^{2}$, Reury Frank Pereira BACURAU ${ }^{1}$, \\ Patrícia Lopes de CAMPOS ${ }^{3}$, Silmara dos Santos LUZ ${ }^{4}$, Antonio Herbert LANCHA Jr ${ }^{3}$ \\ and Julio TIRAPEGUI ${ }^{4}$ \\ ${ }^{1}$ School of Arts, Sciences and Humanities, ${ }^{2}$ School of Public Health, ${ }^{3}$ School of Physical Education and Sports, \\ and ${ }^{4}$ Faculty of Pharmaceutical Sciences, University of São Paulo, Av. Arlindo Bettio 1000, \\ CEP 03808-000, São Paulo, SP, Brazil
}

(Received November 24, 2009)

\begin{abstract}
Summary This study aimed to investigate the effects of physical training, and different levels of protein intake in the diet, on the growth and nutritional status of growing rats. Newly-weaned Wistar rats $(n=48)$ were distributed into six experimental groups; three of them were subjected to physical swim training ( $1 \mathrm{~h}$ per day, $5 \mathrm{~d}$ per week, for $4 \mathrm{wk}$, after 2 wk of familiarization) and the other three were considered as controls (non-trained). Each pair of groups, trained and non-trained, received diets with a different level of protein in their composition: $14 \%, 21 \%$ or $28 \%$. The animals were euthanized at the end of the training period and the following analyses were performed: proteoglycan synthesis as a biomarker of bone and cartilage growth, IGF-I (insulin-like growth factor-I) assay as a biomarker of growth and nutritional status, total RNA and protein concentration and protein synthesis measured in vivo using a large-dose phenylalanine method. As a main finding, increased dietary protein, combined with physical training, was able to improve neither tissue protein synthesis nor muscle growth. In addition, cartilage and bone growth seem to be deteriorated by the lower and the higher levels of protein intake. Our data allow us to conclude that protein enhancement in the diet, combined with physical exercise, does not stimulate tissue protein synthesis or muscle mass growth. Furthermore, physical training, combined with low protein intake, was not favorable to bone development in growing animals.
\end{abstract}

Key Words growth, exercise, protein, bone growth, cartilage growth

Currently, a number of people are involved in physical training practices, for reasons such as health or competitive aims. Different age groups are involved in these practices, including growing individuals (children and teenagers). Despite motives for physical exercising, different dietetic manipulations have been adopted. Enhanced protein intake, from diet or from nutritional supplements, is commonly used, and there is no consensus regarding the health consequences of these practices in growing individuals $(1,2)$.

Nutritional status is considered as the main factor regulating body growth (3), which requires nutrient use to be directed towards cell multiplication, energy storage and skeletal elongation. These processes demand metabolic fuels, together with the presence of systematic regulatory factors, which channel nutrient utilization towards growth $(4,5)$.

As such, analyzing nutritional status together with growth processes in physical training could be mandatory. It is possible to analyse body growth from different tissues, such as muscle and bones, and also from regulatory factors such as specific hormones. For example, measurement of proteoglycan synthesis can give precise information regarding cartilage growth. Growth of long

E-mail: smlribeiro@usp.br bones starts in the epiphyseal cartilage, whose development consists of proteoglycan synthesis and cell multiplication $(6,7)$. One hormone that regulates body growth is IGF-I (insulin-like growth factor-I), which controls the action of growth hormone and acts on tissues, stimulating cell proliferation and synthesis of DNA, RNA, protein and proteoglycans.

Yahya et al. (6) observed a positive correlation between IGF-I and other variables (protein, energy and plasma insulin) in rats previously fed on a $0.5 \%$ casein diet for $3 \mathrm{wk}$ and then refed with different casein percentages in diets. According to these investigators, dietary protein presented the highest correlation with IGF-I. Tirapegui (8), studying rats subjected to low protein diets, found a reduced secretion of IGF-I and slowed synthesis of proteoglycan, RNA and protein, impairing total body and tissue growth. In addition, Gomes et al. (9) reported that a lack of protein in the diet was found to be a regulating factor for IGF-I.

In this study, we investigated the concepts of nutrition, physical exercise and growth, employing an animal model. Since childhood and adolescence are important stages for the body's growth, which in turn is directly linked to nutritional status, we asked the following questions: to what extent are bone and muscle growth stimulated by changes in the percentages of 
protein in the diet? Does physical training have any additive influence on those changes? Based on these questions, the aim of this manuscript is to investigate the effects of physical training and different levels of protein intake in the diet on the growth and nutritional status of growing rats.

\section{METHODS}

Animals and treatments. Newly-weaned Wistar rats $(n=48), 21 \mathrm{~d}$ old, weighing $40-50 \mathrm{~g}$, were obtained from the Animal Laboratory of the Faculty of Pharmaceutical Sciences at the University of São Paulo. The local Ethics Committee approved all experimental procedures, and the guidelines for animal care and use were followed according to the Declaration of Helsinki.

The animals were individually housed in stainlesssteel cages in the animal house at a constant temperature of $22 \pm 2^{\circ} \mathrm{C}$ and humidity of $55 \pm 10 \%$, on an inverted 12-h light/12-h dark cycle (lights on at $1900 \mathrm{~h}$ ). All animals were weighed daily at $0800 \mathrm{~h}$, before the training period. At that time, the water and the non-ingested food was weighed and withdrawn from the cages. After the training period for trained animals, the new food was weighed and offered to the animals, in a specific receptacle inside the cages. During the remaining time, the animals received food and water ad libitum. Therefore, this schedule ensured that animals of all groups (despite being trained or not) had the same time of feeding.

Experimental procedure. The procedures were developed in $6 \mathrm{wk}$; the first week consisted of adaptation to biological cycle inversion. During the second week, the animals were familiarized with the swimming system (10); the rats exercised for $5 \mathrm{~d}$ per week with a growing load attached to the tail that finally reached $5 \%$ of body weight, to achieve an aerobic physical effort (11). Subsequently, from week 3 until the end of the experiment, the trained groups were exercised for $60 \mathrm{~min}$ daily, $5 \mathrm{~d}$ per week, for $4 \mathrm{wk}$. Swimming was always performed at a water temperature of $27-30^{\circ} \mathrm{C}$ between 0800 and $1100 \mathrm{~h} \mathrm{(12).} \mathrm{The} \mathrm{load} \mathrm{attached} \mathrm{to} \mathrm{the} \mathrm{tail} \mathrm{was} \mathrm{adjusted}$ weekly, according to the animals' weight evolution.

The animals were distributed into six experimental groups; three of them were subjected to physical training and the other three were considered as controls (non-trained). Each pair of groups, trained and nontrained, received a diet with a different level of protein in its composition: $14 \%, 21 \%$ or $28 \%$. For this, groups with eight animals were formed as follows; groups subjected to physical training; T14 (14\% protein added to ration), T21 (21\% protein added to ration), T28 (28\% protein added to ration) and their non-trained pairs: NT14, NT21 and NT28. Diets were prepared according to the American Institute of Nutrition, modifying casein and starch proportions (13). It is important to observe that the recommended percentage of protein in the diet is $17.9 \%$ (for growing animals) (13). We intended, therefore, to study diets slightly above and slightly below the recommendation. The chemical composition of the diets is described in Table 1.
Table 1. Composition of experimental diets. ${ }^{1}$

Ingredients $(\mathrm{g} / \mathrm{kg}) \quad 14 \%$ protein $21 \%$ protein $28 \%$ protein

\begin{tabular}{lccc}
\hline Casein $^{2}$ & 165.9 & 248.9 & 331.8 \\
Sucrose & 100 & 100 & 100 \\
Fiber & 50 & 50 & 50 \\
Corn oil & 50 & 50 & 50 \\
Mineral mixture & 35 & 35 & 35 \\
Vitamin mixture & 10 & 10 & 10 \\
DL-Methionine & 1.8 & 0.9 & 0.7 \\
Choline bitartrate & 2 & 2 & 2 \\
Cornstarch & 585.3 & 503.2 & 420.5 \\
Total weight $(\mathrm{g})$ & 1,000 & 1,000 & 1,000 \\
\end{tabular}

${ }^{1}$ Isocaloric diets providing $1,613 \mathrm{~kJ} / 100 \mathrm{~g}(386 \mathrm{kcal} /$ $100 \mathrm{~g}) .{ }^{2}$ Casein contain $85 \%$ protein.

On the day after the last day of training (in week 6), the animals were euthanasied by decapitation. Blood, collected by inversion of the animal, was centrifuged and plasma was stored at $-80^{\circ} \mathrm{C}$ for later biochemical determination. Before euthanasia, the animals were injected intraperitoneally with $0.4 \mu \mathrm{Ci}{ }^{35} \mathrm{~S}$-sodium sulfate (60 min before) and $0.2 \mu \mathrm{Ci}{ }^{3} \mathrm{H}$-phenylalanine (15 min before) per gram body weight for determination of proteoglycan and protein synthesis, respectively $(6,14)$.

The gastrocnemius and soleus muscles were weighed, submerged in liquid nitrogen and stored at $-80^{\circ} \mathrm{C}$ for later determinations. The tibiae of both legs were dissected and their lengths were measured with one caliper and reported as $\mathrm{mm}$. The hyaline cartilage was then extracted, weighed and stored at $-80^{\circ} \mathrm{C}$ for later determinations. The epididimal adipose tissue was gently separated and weighed, and these values were considered when discussing animals' body fat.

Citrate synthase activity determination as a biomarker of training status. The citrate synthase activity was measured in the soleus muscle, according to Alp et al. (15). All spectrophotometric measurements were performed in a Gilford recorder spectrophotometer (Model Response) at $25^{\circ} \mathrm{C}$. The activities of citrate synthase are expressed as mol of substrate utilized per minute per gram of fresh weight.

Proteoglycan synthesis as a biomarker of bone and cartilage growth. A sample of gastrocnemius muscle was weighed, pulverized and homogenized in ice-cold 10\% trichloracetc acid (TCA), washed twice with 10\% TCA and with perchloric acid to remove any residual free ${ }^{35} \mathrm{SO}_{4}$, and solubilized in $2 \mathrm{~mL} 90 \%(\mathrm{w} / \mathrm{v})$ formic acid, after incubation at $90^{\circ} \mathrm{C}$ overnight. ${ }^{35} \mathrm{~S}$ radioactivity was measured in a Beckman LS-150 liquid scintillation counter, and expressed as d.p.m/mg tissue. The epiphysis (including the growth plate) was cleaned of all visible traces of muscle and tendons, cut into small pieces, weighed accurately in a polypropylene test tube, homogenized twice in ice-cold acid-ethanol $(1.25 \mathrm{~mL} / 50 \mathrm{mg})$ to give a final yield of $2.5 \mathrm{~mL}$ supernatant $/ 50 \mathrm{mg}$ tissue for the measurement of tissue IGF-I, and the precipitate was then treated with $10 \%$ TCA as for muscle (6). 
IGF-I assays as a biomarker of growth and nutritional status. Frozen muscle (gastrocnemius) was pulverized between aluminum plates previously immersed in liquid nitrogen. The pulverized samples were placed in polypropylene tubes, also previously immersed in liquid nitrogen, and $85 \%$ ethanol and $15 \% 6 \mathrm{M} \mathrm{HCl}$ were added. IGF-I was extracted twice from $100 \mathrm{mg}$ pulverized tissue in $2.5 \mathrm{~mL}$ ice-cold acid ethanol $(87.5 \%(\mathrm{v} / \mathrm{v})$ ethyl-alcohol and $12.5 \%(\mathrm{v} / \mathrm{v}) \mathrm{HCl}(2 \mathrm{~mol} / \mathrm{L})$ and the combined supernatants were evaporated to dryness under vacuum. Supernatants were then dissolved in $600 \mu \mathrm{L} \mathrm{NaOH}(0.5 \mathrm{~mol} / \mathrm{L})$, neutralized with $\mathrm{HCl}$ $(0.5 \mathrm{~mol} / \mathrm{L})$ and centrifuged again, before drying under vacuum. The extract was reconstituted in $300 \mu \mathrm{L}$ assay buffer and then assayed for IGF-I. A similar procedure was used for the acid-ethanol supernatant of the tibia epiphysis, prepared as described above $(6,7)$.

The extracts and plasma (also acid-ethanol extracted to dissociate and separate IGF-I from binding proteins) were analysed for IGF-I by radioimmunoassay (RIA). The neutralized supernatant was incubated with a rabbit polyclonal anti-human IGF-I first antibody and labeled human IGF-I ( ${ }^{125}$ I-labelled IGF-I). After an overnight incubation, the IGF-I-antibody complex was precipitated by a polyethylene glycol (PEG)-globulin mix acting as a non-specific secondary antibody $[125 \mathrm{~mL}$ $40 \%$ (w/v) PEG-6000/50 mL $0.2 \mathrm{~mol}$ Tris-Cl/L buffer, $\mathrm{pH}$ 8.5/25 mL distilled water/0.3 rabbit gamma-globulin (Sigma, Norbiton, Surrey, UK)].

Total RNA and protein concentration. RNA and protein analyses were performed on gastrocnemius muscle and cartilage according to Lowry et al. (16) and Munro and Fleck (17), respectively.

Protein synthesis. Cartilage and gastrocnemius muscle protein synthesis (Ks, \%/d) was measured in vivo using a large-dose phenylalanine method. The large dose of amino acids results in a rapid rise in specific radioactivity of free phenylalanine in tissues to values close to that of plasma, followed by a slow but linear fall. This enables the rate of protein synthesis to be calculated from measurements of the specific radioactivity of free and protein-bound phenylalanine in tissues during a $10 \mathrm{~min}$ period after injection of the radioisotope. Labeled compounds were purchased from Amersham, Bucks, UK, and were evaporated to dryness before being dissolved in the appropriate injection solution. LTyrosine decarboxylase, B-phenetylamine and leucylalanine were purchased from Sigma (London) Chemical Co., Poolet, Dorset, UK, and ninhydrin was from BDH, Poole, Dorset, UK (14).

Data analysis. Data were confirmed for normality and homogeneity using Levene's test. The results were then submitted to factorial analysis of variance (ANOVA). When any significant difference $(p<0.05)$ was found, the Tukey post-hoc was performed as follows: For comparison among groups with the same level of physical activity, looking for differences among different levels of dietetic proteins: a) $\mathrm{T} 14 \times \mathrm{T} 21 \times \mathrm{T} 28$; b) NT1 $4 \times \mathrm{NT} 21 \times \mathrm{NT} 28$. Differences found in these analyses $(p<0.05)$ are shown as different letters,

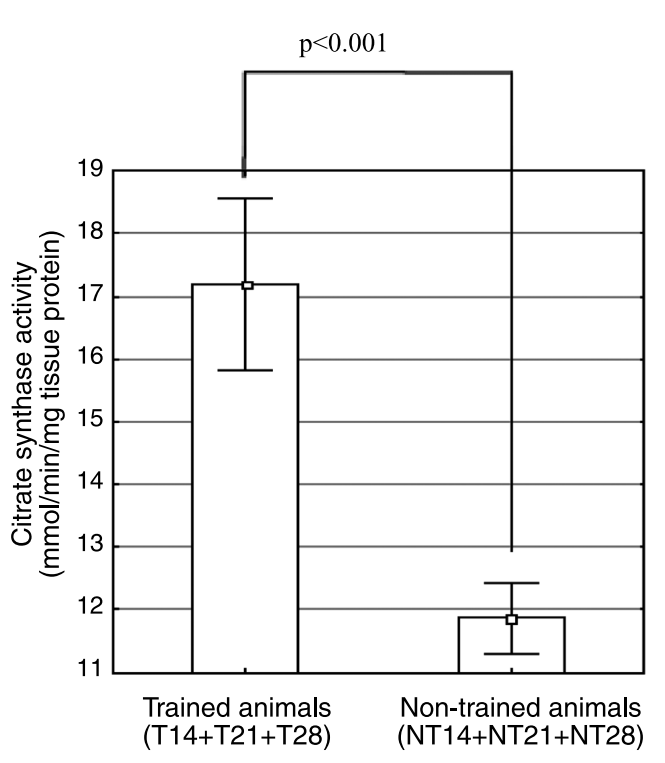

Fig. 1. Citrate synthase activity from soleus muscle, comparing trained and non-trained groups (mean \pm $\mathrm{SD} ; t$-test for independent variables).

between parentheses (described in all graphs and tables); for comparison between trained and nontrained animals, considering the same level of physical

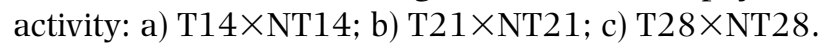
For the analysis of citrate synthase only, the comparison was made using the Student $t$-test for independent samples, considering all the trained animals against all the non-trained animals.

\section{RESULTS}

Figure 1 demonstrates the efficacy of physical training, since the citrate synthase activity was significantly enhanced in trained animals, compared with nontrained ones $(p=0.001)$. Table 2 presents variables related to body growth, food intake and fat deposits. None of the treatments resulted in any difference in food intake. Trained groups did not present different body weights when the levels of protein intake were compared. In contrast, in non-trained animals, the NT14 group (lower protein intake) presented a lower body weight, compared to other protein intake levels ( $p<0.05$, for both comparisons). When the comparison was made between trained animals and their nontrained pairs, trained animals presented significantly lower body weight despite the protein intake $(p<0.05$, for all comparisons). With regard to epididimal adipose tissue, there were no differences among the different protein levels in the trained groups. However, among non-trained groups, the higher protein intake $(28 \%)$ resulted in a higher epididimal adipose tissue weight $(p<0.05$, when compared either with $14 \%$ or $21 \%$ ). When the comparison was made between trained animals and their non-trained pairs, only the $28 \%$ protein group (NT28) presented increased weight in this tissue $(p<0.05$, when compared either with $14 \%$ or $21 \%)$. With regard to tibia length, the only difference found was in the comparison between trained and non- 
Table 2. Food intake and biometric variables (mean \pm SD) of experimental animals (mean \pm SD).

\begin{tabular}{ccccc}
\hline Experimental groups & Food intake $(\mathrm{g})$ & Final body weight $(\mathrm{g})$ & Epididymal adipose tissue $(\mathrm{g})$ & Tibial length $(\mathrm{mm})$ \\
\hline & & Trained animals & \\
T14 & $429 \pm 41(\mathrm{a})$ & $91.8 \pm 17.2(\mathrm{a} *)$ & $1.02 \pm 0.23(\mathrm{a})$ & $34.32 \pm 0.87(\mathrm{a} *)$ \\
T21 & $397 \pm 56(\mathrm{a})$ & $95.4 \pm 20.4(\mathrm{a} \$)$ & $1.10 \pm 0.23(\mathrm{a})$ & $35.80 \pm 1.28(\mathrm{a})$ \\
T28 & $408 \pm 27(\mathrm{a})$ & $101.0 \pm 14.2(\mathrm{a} \#)$ & $0.83 \pm 0.10(\mathrm{a} \#)$ & $35.57 \pm 0.47(\mathrm{a})$ \\
\hline & & \multicolumn{2}{c}{ Non-trained animais } & $36.02 \pm 1.12(\mathrm{a} *)$ \\
NT14 & $438 \pm 75(\mathrm{a})$ & $213.4 \pm 14.1(\mathrm{a}, \mathrm{C} *)$ & $0.96 \pm 0.12(\mathrm{a})$ & $36.92 \pm 0.90(\mathrm{a})$ \\
NT21 & $470 \pm 56(\mathrm{a})$ & $250.7 \pm 29.2(\mathrm{~b} \$)$ & $1.01 \pm 0.11(\mathrm{a})$ & $36.82 \pm 1.00(\mathrm{a})$ \\
NT28 & $431 \pm 74(\mathrm{a})$ & $234.3 \pm 25.8(\mathrm{~b}, \mathrm{c} \#)$ & $1.46 \pm 0.49(\mathrm{~b} \#)$ &
\end{tabular}

Results of statistical analysis are between parentheses; different letters represent significanct difference among the animals with the same physical activity level $(\mathrm{T} 14 \times \mathrm{T} 21 \times \mathrm{T} 28$ or $\mathrm{NT} 14 \times \mathrm{NT} 21 \times \mathrm{NT} 28)$; symbols: $*$, difference between T14 $\times$ NT14; \$, difference between T21×NT21; \#, difference between T28×NT28.

Table 3. Growth and protein synthesis biomarkers in gastrocnemius muscle tissue (mean $\pm \mathrm{SD})$.

\begin{tabular}{|c|c|c|c|c|c|}
\hline Groups & $\begin{array}{l}\text { Muscle weight } \\
(\mathrm{g})\end{array}$ & $\begin{array}{l}\text { Tissue RNA concentration } \\
(\mu \mathrm{g} / 100 \mathrm{mg})\end{array}$ & $\begin{array}{l}\text { Tissue protein content } \\
\quad(\mathrm{mg} / 100 \mathrm{mg})\end{array}$ & $\begin{array}{l}\text { Protein synthesis } \\
\quad(\mathrm{Ks})(\% / \mathrm{d})]\end{array}$ & $\begin{array}{c}\text { Ribose capacity } \\
{[\operatorname{RNA}(\mu \mathrm{g}) / \operatorname{prot}(\mathrm{mg})]}\end{array}$ \\
\hline & \multicolumn{5}{|c|}{ Trained animals } \\
\hline $\mathrm{T} 14$ & $1.23 \pm 0.11(\mathrm{a})$ & $133.46 \pm 9.55$ (a) & $10.26 \pm 1.81(\mathrm{a})$ & $17.34 \pm 6.55(\mathrm{a})$ & $13.50 \pm 3.30(\mathrm{a})$ \\
\hline $\mathrm{T} 21$ & $1.39 \pm 0.18(\mathrm{a} \$)$ & $130.72 \pm 13.50(\mathrm{a})$ & $9.85 \pm 2.53$ (a) & $10.07 \pm 2.65$ (a) & $14.18 \pm 4.41(\mathrm{a})$ \\
\hline $\mathrm{T} 28$ & $1.32 \pm 0.14(\mathrm{a})$ & $135.32 \pm 9.43$ (a) & $7.87 \pm 0.65$ (a) & $9.15 \pm 2.37$ (a) & $17.33 \pm 2.29$ (a) \\
\hline \multicolumn{6}{|c|}{ Non-trained animals } \\
\hline NT14 & $1.38 \pm 0.14(\mathrm{a}, \mathrm{c})$ & $135.36 \pm 12.78(a)$ & $7.79 \pm 2.46(\mathrm{a})$ & $9.50 \pm 0.76$ (a) & $18.52 \pm 4.46(\mathrm{a})$ \\
\hline NT21 & $1.63 \pm 0.17(\mathrm{~b} \$)$ & $138.43 \pm 17.20(\mathrm{a})$ & $7.21 \pm 1.67(\mathrm{a})$ & $7.76 \pm 0.85$ (a) & $20.20 \pm 5.64(\mathrm{a})$ \\
\hline NT28 & $1.55 \pm 0.16(b, c)$ & $137.51 \pm 13.14(\mathrm{a})$ & $7.48 \pm 2.75$ (a) & $12.21 \pm 2.40(\mathrm{a})$ & $20.49 \pm 6.86$ (a) \\
\hline
\end{tabular}

Results of statistical analysis are between parentheses; different letters represent significant difference among the animals with the same physical activity level $(\mathrm{T} 14 \times \mathrm{T} 21 \times \mathrm{T} 28$ or NT14 $\times$ NT2 $1 \times \mathrm{NT} 28)$; symbols: $*$, difference between T14 and NT14; \$, difference between T21 and NT21; \#, difference between T28 and NT28.

Table 4. Growth and protein synthesis biomarkers in cartilage tissue (mean \pm SD).

\begin{tabular}{|c|c|c|c|c|c|c|}
\hline Group & $\begin{array}{c}\text { Cartilage } \\
\text { weight }(\mathrm{g})\end{array}$ & $\begin{array}{c}\text { Tissue RNA } \\
\text { concentration } \\
(\mu \mathrm{g} / 100 \mathrm{mg})\end{array}$ & $\begin{array}{l}\text { Tissue protein } \\
\text { content } \\
(\mathrm{mg} / 100 \mathrm{mg})\end{array}$ & $\begin{array}{l}\text { Proteoglycan } \\
\text { synthesis } \\
\text { (cpm/100 mg) }\end{array}$ & $\begin{array}{c}\text { Protein } \\
\text { synthesis } \\
(\mathrm{Ks})(\% / \mathrm{d})\end{array}$ & $\begin{array}{c}\text { Ribose capacity } \\
{[\mathrm{RNA}(\mu \mathrm{g}) /} \\
\operatorname{prot}(\mathrm{mg})]\end{array}$ \\
\hline & \multicolumn{6}{|c|}{ Trained animals } \\
\hline $\mathrm{T} 14$ & $0.039 \pm 0.003$ (a) & $73.12 \pm 8.31(\mathrm{a})$ & $59.82 \pm 11.87(\mathrm{a} *)$ & $2,702.8 \pm 581.9(\mathrm{a} *)$ & $30.9 \pm 11.1$ (a) & $1.35 \pm 0.19$ (a) \\
\hline $\mathrm{T} 21$ & $0.039 \pm 0.008$ (a) & $65.09 \pm 9.78(\mathrm{a} \$)$ & $75.29 \pm 29.64(\mathrm{a} \$)$ & $3,173.2 \pm 529.3$ (a) & $43.8 \pm 12.6$ (a) & $0.91 \pm 0.29$ (a) \\
\hline $\mathrm{T} 28$ & $0.040 \pm 0.007$ (a) & $73.02 \pm 12.96(\mathrm{a} \#)$ & $75.28 \pm 16.24(\mathrm{a})$ & $2,176.4 \pm 335.8$ (a) & $40.2 \pm 12.0$ (a) & $1.00 \pm 0.28$ (a) \\
\hline
\end{tabular}

\begin{tabular}{|c|c|c|c|c|c|}
\hline & \multicolumn{5}{|c|}{ Non-trained animals } \\
\hline NT14 & $0.028 \pm 0.004$ (a) $103.68 \pm 33.92$ (a) & $23.25 \pm 10.94(\mathrm{a} *)$ & $4,417.9 \pm 669.9(\mathrm{a} *)$ & $56.3 \pm 15.0(\mathrm{a})$ & $5.42 \pm 3.08$ \\
\hline NT21 & $0.028 \pm 0.003(\mathrm{a}) 135.18 \pm 84.14(\mathrm{~b} \$)$ & $32.85 \pm 12.58(\mathrm{a} \$)$ & $3,847.7 \pm 674.5$ (a) & $51.9 \pm 9.4(\mathrm{a})$ & $3.97 \pm 1.52(a$ \\
\hline NT28 & $0.029 \pm 0.002$ (a) $180.54 \pm 24.73(b \#)$ & $67.67 \pm 13.08(b)$ & $3,262.4 \pm 83.5$ (a) & $44.1 \pm 16.2$ (a) & $2.70 \pm 0.28(\mathrm{a}$ \\
\hline
\end{tabular}

Results of statistical analysis are between parentheses; different letters represent significant difference among the animals with the same physical activity level $(\mathrm{T} 14 \times \mathrm{T} 21 \times \mathrm{T} 28$ or $\mathrm{NT} 14 \times \mathrm{NT} 21 \times \mathrm{NT} 28)$; symbols: $*$, difference between $\mathrm{T} 14 \times$ NT14; \$, difference between T21×NT21; \#, difference between T28×NT28.

trained group with $14 \%$ protein; the non-trained group presented a longer tibia length $(p<0.05)$.

Table 3 presents the gastrocnemius muscle analysis. Different protein intakes in the trained groups did not result in any difference in muscle weight. In contrast, in non-trained animals, $14 \%$ protein resulted in a lower muscle weight $(p<0.05$, when compared with $21 \%$ and
$28 \%)$. Comparing trained animals and their nontrained pairs, $21 \%$ protein resulted in higher muscle weight in non-trained animals $(p<0.05)$. No significant difference was found for any treatment with regard to RNA concentration, protein concentration, or protein synthesis or ribosomal capacity.

Table 4 presents cartilage tissue analysis. None of the 

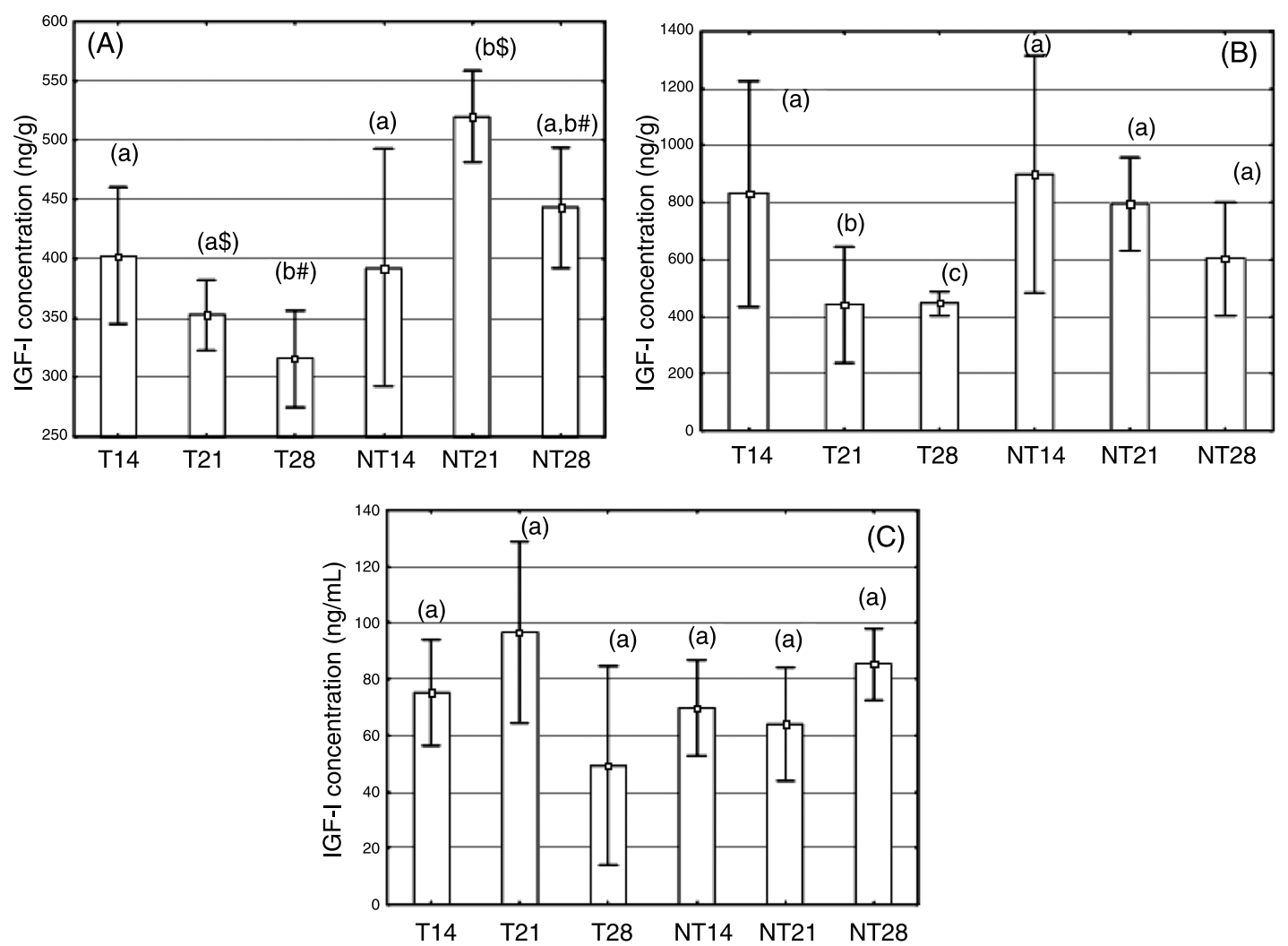

Fig. 2. IGF-I concentration in experimental groups (mean \pm SD). (A) gastrocnemius muscle; (B) tibial epiphyseal cartilage; (C) plasma levels. Statistical differences between parentheses: different letters represent difference $(p<0.05)$ among the

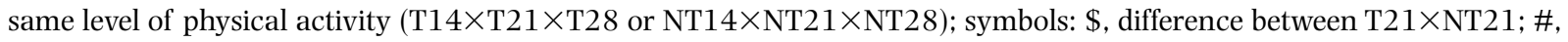
difference between T28×NT28.

treatments resulted in any difference in cartilage weight. No differences were found in RNA concentration, protein concentration, proteoglycan synthesis, protein synthesis or ribosomal capacity among trained animals, when the different levels of protein intake were compared. Among the non-trained groups, $14 \%$ protein resulted in the lowest RNA concentration $(p<0.05$, when compared with the two other protein levels), whilst $28 \%$ protein resulted in a higher protein concentration in this tissue $(p<0.05$, when compared with the two other protein levels). When trained and nontrained animals were compared, non-trained animals presented higher RNA concentrations for the $21 \%$ protein diet $(p<0.05)$ and 28\% $(p<0.05)$; non-trained animals presented higher proteoglycan synthesis only with $14 \%$ protein $(p<0.05$, when compared either with $21 \%$ or $28 \%$ ). No difference was observed among treatments with regard to protein synthesis or ribosomal capacity.

Figure 2 presents the IGF-I levels in the gastrocnemius muscle (panel A), cartilage (panel B) and plasma (panel C). It may be noted, among trained groups, that $28 \%$ protein corresponds to lower levels of this hormone, both in the muscle tissue $(p<0.05$, when compared with $14 \%$ or $21 \%$ ) and in cartilage tissue [ $28 \%$ is lower than $21 \%(p<0.05)$ and than $14 \%(p<0.05)$; $21 \%$ is lower than $14 \%(p<0.05)]$. It was not possible to identify, among non-trained groups fed with different protein levels, a clear difference in IGF in either muscle tissue or cartilage tissue. When the comparison was made between trained and paired non-trained animals, the trained groups presented lower IGF-I levels in the muscle when the protein intake was $21 \%(p<0.05)$ and $28 \%(p<0.05)$. Plasma IGF-I levels were not significantly different among different treatments.

\section{DISCUSSION}

We investigated the effects of different protein levels, given in the diet, in combination with physical training, on markers of growth and nutritional status in rats. Our main finding was that an increase in dietary protein, combined with physical training, was able to improve neither tissue protein synthesis nor muscle growth. In addition, cartilage and bone growth seems to be deteriorated by the lower and the higher levels of protein intake.

From our results, we may conclude that the hypothesis that protein enhancement in the diet could improve body and tissue growth was not confirmed; and this finding is in disagreement with many published papers. Studies performed with adults (both with animals and humans) have suggested that high protein diets, combined with physical training, result in lower body fat and higher fat-free mass $(18,19)$. Studies have indicated that, among the benefits of this kind of diet, a reduction in liver lipogenesis may be observed $(18,20)$. We can speculate that the growing condition of the animals modifies amino acid metabolism, allowing a deviation of the carbon skeleton from the excessive amino 
acids to glucose and fatty acids synthesis, favoring lipogenesis (21).

Our results may be explained by the energy/protein ratio. Sports nutrition position statements agree that when increasing total protein intake, the ratio between energy and protein intake is essential to fulfill the cells' requirement for protein synthesis (22). Our data could indicate an imbalance between energy and protein intake from the diet, since the starch content was reduced to enhance the protein from the diet. The protein-sparing effects of carbohydrates have been highlighted by many researchers for a long time $(23,24)$. This protein-sparing effect is thought to be mediated in part by increased insulin secretion, which inhibits proteolysis, hepatic gluconeogenesis and renal amoniagenesis (23). Considering the absence of a significant difference in food intake among groups, the higher proportion of protein in the high-protein groups could be deviated to desamination reactions and, consequently, the carbon skeleton utilized for the energy needs of these growing animals (24). Therefore, it could be suggested that the excess of amino acids was oxidized by the animals. Nakazato and Song (25) evaluated the effects of a high-protein diet on oxidative capability in the gastrocnemius muscle of growing rats, and observed an enhanced amino acid oxidation. These findings could explain our results, indicating that excess protein in the high-protein group could be oxidized, instead of being incorporated into new protein molecules (26).

We made use of labeled phenylalanine to analyse protein synthesis and, despite the different treatments (exercise or different protein level), we did not find any significant difference among experimental groups. Previous studies have shown that protein synthesis and degradation processes are precisely counterbalanced (27). With regard to protein synthesis, other studies employing high-protein diets have shown changes either in stimulating or inhibiting factors of protein turnover, resulting in controversial results for muscle growth patterns. For example, Layman et al. (28) demonstrated that by enhancing protein in the diet, it is possible to enhance available leucin, which in turn is capable of activating the mTOR (mammalian target of rapamycin) system and stimulating elongation factors (eIF) (29). Conversely, the action of the mTOR system is opposed by myostatin, which inhibits muscle growth via gene transcription $(29,30)$. Myostatin is considered a potent inhibitor of protein synthesis since it prevents satellite cell activation, even if high amino acid intake stimulates the mTOR/eIF pathway. Nakazato et al. (31) studied the effects of a high protein diet on myostatin action in growing animals (4 wk old). According to these authors, a hyperaminoacidemia, resulting from high protein diets, induced an enhanced expression of myostatin. Therefore, these findings from different studies may illustrate the complexity of protein turnover. It seems possible that, in our experiment, the high-protein diet could direct the higher expression of myostatin or other inhibitors of protein synthesis in growing ani- mals.

With regard to processes related to bone growth, tibia length and proteoglycan synthesis were reduced when we combined physical training and low protein intake. There are many controversies related to protein ingestion and bone growth. Although many studies over the last $80 \mathrm{y}$ have demonstrated a link between high-protein intake and urinary excretion of nitrogen (32), recent evidence shows positive effects of protein on bone health. Additionally, it is known that physical training improves bone quality, ameliorating both mineral density and protein content (33). However, the benefits of physical training have to be supported by an adequate intake of protein, an important osteotrophic nutrient $(7,34-36)$; otherwise a negative nitrogen balance may be created, making it impossible for the osteoblasts to lay down the necessary organic matrix, which is the first step in the formation of bone (37). As such, our data demonstrate that $14 \%$ protein was not sufficient to maintain the potential of bone growth $(36,38$, 39).

IGF-I, either in plasma or tissues, was not reduced by low protein intakes. In contrast, the higher protein level resulted in lower IGF-I concentrations in the cartilage and muscle. Observing these findings, in parallel with proteoglycan synthesis and tibia length, it is possible to infer that the optimum protein level to be ingested by these growing animals is probably around $21 \%$. We did not find any beneficial effects at above or below this percentage.

Another interesting finding of our study is that IGF-I concentrations were reduced only in muscle and cartilage; plasma values were not modified by treatments. This finding is in agreement with recent evidence related to the "classical somatomedin hypothesis." Yakar et al. (40), using a transgenic approach with tissue-specific gene deletions of IGF-I, proposed a "dual somatomedin hypothesis," according to which autocrine/paracrine IGF-I is the main determinant of postnatal body growth. In addition, the authors state that liver-derived, endocrine-acting, IGF-I exerts negative feedback effects on GH secretion. Endocrine-acting liver-derived IGF-I may also exert other effects, including regulation of carbohydrate and lipid metabolism (41).

From our data, it may be supposed that growing rats could present different metabolic behaviors according to different levels of protein intake. Although there is no doubt that an adequate protein intake during growth is essential to support normal growth and skeletal development, more research is needed to evaluate the upper and lower thresholds of this nutrient in the diet, and/or the ideal energy/protein rate in growing individuals. However, our study was unable to identify the precise mechanism of this balance. More studies are necessary, including investigations of molecular variables related to protein synthesis stimulators and inhibitors. Furthermore, different physical training methods, including resistance exercise, could produce interesting findings. 
Finally, our data allow us to conclude that enhancing protein in the diet, combined with physical exercise, does not exert any influence on tissue protein synthesis or muscle mass. Furthermore, physical training combined with low protein intake was not favorable for bone development in growing animals.

\section{REFERENCES}

1) O'dea JA. 2003. Consumption of nutritional supplements among adolescents: usage and perceived benefits. Health Educ Res 18: 98-107.

2) Bell A, Dorsch KD, Mccreary DR, Hovey R. 2004. A look at nutritional supplement use in adolescents. J Adolesc Health 34: 508-516.

3) Prewitt TE, D’Ercole AJ, Switzer BR, Van Wyk JJ. 1982. Relationship of serum immunoreactive somatomedin-C to dietary protein and energy in growing rats. J Nutr 112: $144-150$.

4) Millward DJ, Bates PC, Coyer P, Cox M, Dalal S, Jepson M, Pell J. 1986. The effect of dietary energy and protein on growth as studied in animal models. In: Energy and Protein Needs during Infancy (Fomon SJ, Heird WC, eds), p 127-156. Academic Press, London.

5) Phillips LS, Harp JB, Goldstein S, Klein J, Pao CI. 1990. Regulation and action of insulin-like growth factors at the cellular level. Proc Nutr Soc 49: 451-458.

6) Yahya ZAH, Bates PC, Millward DJ. 1990. Responses to protein deficiency of plasma and tissue insulin-like growth factor-I levels and proteoglycan synthesis rates in rat skeletal muscle and bone. J Endocrinol 127: 497503.

7) Yahya ZAH, Tirapegui J, Bates PC, Millward DJ. 1994. Influence of dietary protein, energy and corticosteroids on protein turnover, proteoglycan sulphation and growth of long bone and skeletal muscle in the rat. Clin Sci 87: 607-618.

8) Tirapegui J. 1999. Effect of insulin-like growth factor-1 (IGF-1) on muscle and bone growth in experimental models. Int J Food Sci Nutr 50: 231-236.

9) Gomes MR, Pires ISO, Castro IA, Tirapegui J. 2003. Effect of protein restriction on plasma and tissue levels of insulin-like growth factor-1 (IGF-1) in adult rats. Nutr Res 23: 1239-1250.

10) Curi R, Hell S, Tomi-Iaria C. 1990. Meal feeding and physical effort I. Metabolic changes induced by exercise training. Physiol Behav 47: 869-873.

11) Lancha AH Jr, Recco MB, Abdalla DSP, Curi R. 1995. Effect of aspartate, asparagine, and carnitine supplementation in the diet on metabolism of skeletal muscle during a moderate exercise. Physiol Behav 57: $367-$ 371.

12) Vieira R, Haebisch H, Kokubun E, Hell NS, Curi R. 1988. Swimming system for physical exercise of rats. Arq Biol Tecnol 31: 387-394.

13) Reeves PG, Nielsen FH, Fahey GC Jr. 1993. AIN-93 purified diets for laboratory rodents: final report of the American Institute of Nutrition ad hoc writing committee on the reformulation of the AIN-76A rodent diet. J Nutr 123: 1939-1951.

14) Garlick PJ, McNurlan MA, Preedy VR. 1980. A rapid and convenient technique for measuring the rate of protein synthesis in tissues by injection of $\left[{ }^{3} \mathrm{H}\right]$ phenylalanine. Biochem J 192: 719-723.

15) Alp PR, Newsholme EA, Zammit VA. 1976. Activities of citrate synthase and $\mathrm{NAD}^{+}$-linked and $\mathrm{NADPH}^{+}$-linked isocitrate dehydrogenase in muscle from vertebrates and invertebrates. Biochem J 154: 689-700.

16) Lowry DH, Rosebrough NJ, Farr AL, Rendall RJ. 1951. Protein measurement with folin, phenol reagent. J Biol Chem 19: 266-275.

17) Munro HN, Fleck A. 1966. The determination of nucleic acids. Methods Biochem Anal 14: 113-176.

18) Kinzig KP, Hargrave SL, Hyun J, Moran TH. 2007. Energy balance and hypothalamic effects of a high protein/low carbohydrate diet. Physiol Behav 92: 454-460.

19) Hochstenbach-Waelen A, Veldhorst MAB, Nieuwenhuizen AG, Westerterp-Plantenga MS, Westerterp KR. 2009. Comparison of 2 diets with either $25 \%$ or $10 \%$ of energy as casein on energy expenditure, substrate balance, and appetite profile. Am J Clin Nutr 89: 831-838.

20) Belobrajdic D, McIntosh G, Owens J. 2003. The effects of dietary protein on rat growth, body composition and insulin sensitivity. Asia Pacif J Clin Nutr 12 (Suppl): S42.

21) Nelson DL, Cox MM. 2005. Lehninger: Principles of Biochemistry, 1119 p. WH Freeman \& Company, New York.

22) American College of Sports Medicine; American Dietetic Association; Dietitians of Canada. 2009. Joint Position Statement. Nutrition and Athletic Performance. Med Sci Sports Exerc 32: 2130-2145.

23) World Health Organization. 2007. Protein and amino acids requirements in human nutrition. Report of a joint WHO/FAO/UNU expert consultation. World Health Organ Tech Rep Ser 935: 1-265, back cover.

24) World Health Organization. 1985. Energy and protein requirements. Report of a joint WHO/FAO/UNU expert consultation. World Health Organ Tech Rep Ser 724: 1206.

25) Nakazato K, Song H. 2008. Increased oxidative properties of gastrocnemius in rats fed on a high-protein diet. $J$ Nutr Biochem 19: 26-32.

26) Gaine PC, Pikosky MA, Bolster DR, Martin WF, Maresh CM, Rodriguez NR. 2007. Postexercise whole-body protein turnover response to three levels of protein intake. Med Sci Sports Exerc 39: 480-486.

27) Millward DJ, Garlick PJ. 1972. The pattern of protein turnover in the whole animal and the effect of dietary variations. Proc Nutr Soc 31: 257-263.

28) Layman DK, Evans EM, Erickson D, Seyler J, Weber J, Bagshaw D, Griel A, Psota T, Kris-Etherton P. 2009. A moderate-protein diet produces sustained weight loss and long-term changes in body composition and blood lipids in obese adults. J Nutr 139: 514-521.

29) Wackerhage H, Ratkevicius A. 2008. Signal transduction pathways that regulate muscle growth. Essays Biochem 44: 99-108.

30) Hübner C, Riebel T, Kömen W, Schuelke M, Wagner KR, Stolz LE, Braun T, Tobin JF, Lee S. 2004. Myostatin mutation associated with gross muscle hypertrophy in a child. N Engl J Med 350: 2682-2688.

31) Nakazato K, Hirose T, Song H. 2006. Increased myostatin synthesis in rat gastrocnemius muscles under highprotein diet. Int J Sport Nutr Exerc Metab 16: 153-165.

32) Ginty F. 2003. Dietary protein and bone health. Proc Nutr Soc 62: 867-876.

33) Bailey DA, Malina RM, Rasmussen RL. 1978. The influence of exercise, physical activity, and athletic performance on the dynamics of human growth. In: Human Growth (Falkner F, Tanner JM, eds), Vol 2, p 475-505. Plenum Press, New York. 
34) Loveridge N, Farquharson C, Scheven BAA. 1990. Endogenous mediators of growth. Proc Nutr Soc 49: 443-450.

35) Schaefer L, Iozzo RV. 2008. Biological functions of the small leucine-rich proteoglycans: from genetic to signal transduction. J Biol Chem 283: 21305-21309.

36) Bonjour JP. 2005. Dietary protein: an essential nutrient for bone health. J Am Coll Nutr 24: 526S-536S.

37) Albright F, Smmith PH, Richardson AM. 1941. Postmenopausal osteoporosis. JAMA 116: 2645-2674.

38) Bopp MJ, Houston DK, Lenchik L, Easter L, Kritchevsky SB, Nicklas BJ. 2008. Lean mass loss is associated with low protein intake during dietary-induced weight loss in postmenopausal women. J Am Diet Assoc 108: 1216-
1220.

39) Campbell B, Kreider RB, Ziegenfuss T, Bounty PL, Roberts M, Burke D, Landis J, Lopez H, Antonio J. 2007. International society of sports nutrition position stand: protein and exercise. J Int Soc Sports Nutr 45: 8-14.

40) Yakar S, Liu JL, Le Roith D. 2000. The growth hormone/insulin-like growth factor-I system: implications for organ growth and development. Pediatr Nephrol 14: 544-549.

41) Ohlsson C, Sjögren K, Jansson JO, Isaksson OGP. 2000. The relative importance of endocrine versus autocrine/ paracrine insulin-like growth factor-I in the regulation of body growth. Pediatr Nephrol 14: 541-543. 